\title{
PENYELENGGARAAN FUNGSI DAN WEWENANG LEMBAGA BAITUL MAL DALAM PENGELOLAAN ZAKAT DI KABUPATEN ACEH BARAT [Studi ImplementasiQanun 10 tahun 2018 tentang Baitul Mal]
}

\author{
Budi Handoyo \\ Alumni S2 Magister Ilmu Hukum Universitas Syiah Kuala \\ Dosen pada prodi Hukum Tata Negara STAIN Teungku Dirundeng Meulaboh \\ handoyobudi78@gmail.com
}

\begin{abstract}
Qanun Number 10 of 2018 concerning Baitul Mal is the legal basis for the Baitul Mal to carry out its functions and authorities in managing and managing zakat, waqaf, and religious assets. However, the functions and authority of the Baitul Mal have not been fully implemented, including the lack of socialization from the Baitul Mal so that there are still muzaki who do not submit their zakat to Baitul Mal, in collecting and utilizing zakat there are still many obstacles faced by Baitul Mal. The obstacles faced in the management of zakat by Baitul Mal Aceh include inadequate quality of implementing human resources, capacity, inadequate organizational structure, regulatory aspects that are not in line between regional levels and aspects of socialization and institutional understanding of the community. The efforts made by Baitul Mal to overcome the obstacles faced in the management of zakat are preparing implementing regulations from the Aceh Qanun regarding Baitul Mal, strengthening institutions and personnel (capacity building), expanding the socialization of the roles and functions of Baitul Mal Aceh, Regency / City Baitul Mal and Baitul Village mall, and build cooperation and coordination with all related agencies.
\end{abstract}

Keywords :Baitul Mal Institution In Zakat Management In West Aceh District

$$
\text { نبذة مختصرة }
$$

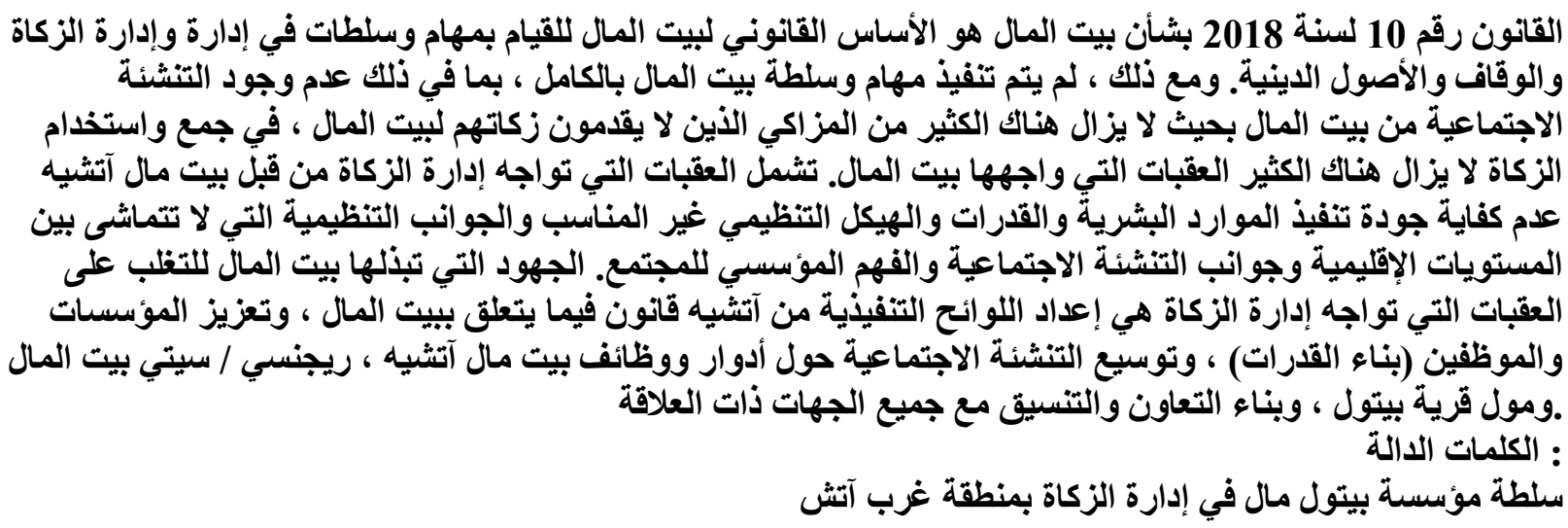

\section{PENDAHULUAN}

Baitul Mal atau Baitul Mal Wat Tamwil begitu sering diperbincangkan belakangan ini seiring dengan upaya umat untuk berekonomi sesuai syariah khususnya di daerah Nanggroe Aceh Darusalam. Menyangkut berkontribusi menanggulangi krisis ekonomi yang melanda Indonesia sejak tahun 1997. 
Namun Baitul Mal atau Baitul Wat Tamwil disingkat dengan BMT ternyata dipahami secara sempit sebagai lembaga ekonomi privat yang nengurusi aspek ekonomi umat, seperti Wadhia atau Mudharabah.

Padahal sesungguhnya Baitul Mal bukanlah lembaga privat atau swasta, melainkan sebuah lembaga yang mengurusi segala pemasukan dan pengeluaran dari negara Islam (khilafiah). Baitul Mal dalam pengertian ini dipraktekkan dalam sejarah Islam sejak masa Rasullullah, diteruskan oleh para Khalifah sesudahnya Abu Bakar, Umar, Usman dan Ali Bin Abi Thalib, serta para Khalifah Bani Umawiyah, Bani Abbas, hingga kehancuran Khilafah di Turki 1942. Gagasan Baitul Mal yang ideal perlu disusun dengan merujuk pada ketentuan-ketentuan syari'ah, baik dalam sumber-sumber pendapatan maupun dalam hal pengelolaannya.

Istilah Baitul Mal belakangaini populer seiring dengan semangat umat untuk berekonomi secara Islam khususnya di Provinsi Aceh dan memberikan solusi terhadap krisis ekonomi yang terjadi di Indonesia 1977 Istila-istilah itu biasanya dipakai oleh lembaga khusus (dalam sebuah perusahaan atau instansi) yang bertugas menghimpun dan menyalurkan zakat, infaq, shadaqah (ZIS) dari para pegawai atau karyawannya.

Istilah tersebut dipakai pula untuk sebuah lembaga ekonomi yang berbentuk koperasi serba usaha yang bergerak di berbagai lini kegiatan ekonomi umat, yakni dalam kegiatan sosial, keuangan, dan usaha pada sektor rill. Oleh karena itu, niat dan semangat yang tinggi untuk berekonomi Islam tersebut patut dihargai. Akan tetapi, penggunaan istilah Baitul Mal tersebut perlu dipertimbangkan lagi secara bijaksana, karena penggunaan istilah
Baitul Mal sekarang ini adalah suatu reduksi kalau tidak dapat dikategorikan distorsi terhadap ketentuan syari'ah Islam menyangkut Baitul Mal.

Dalam konsep aslinya seperti yang tersebut dalam ketentuan syara' maupun praktek konkritnya dalam sejarah islam Baitul Mal merupakan salah satu lembaga dalam negara Islam yang tugas utamanya adalah mengelolah segala pemasukan dan pengeluaran negara. Baitul Mal merupakan lembaga keuangan negara yang bertugas menerima, menyimpan, dan mendistribusikan uang negara sesuai ketentuan syariat, Ringkasnya Baitul Mal dapat disamakan dengan kas negara.

Pemberlakuan Syariat Islam di Aceh berdasarkan Undang-undang Nomor 44Tahun 1999 tentang Penyelenggaraan Keistimewaan Provinsi Daerah Istimewa Aceh telah mendorong Pemerintah Aceh untuk membentuk lembaga-lembaga yang didasarkan pada ketentuan hukum Islam yang sesuai dengan kebutuhan masyarakat Aceh. Salah satu lembaga tersebut adalah Baitul Mal. Lembaga ini sangat strategis dan penting keberadaannya dalam rangka mengoptimalkan pendayagunaan zakat, waqaf dan harta agama sebagai potensi ekonomi umat Islam yang perlu dikelola secara efektif oleh sebuah lembaga profesional yang bertanggung jawab.

Aceh yang memiliki kekhususan dalam beberapa regulasi tentang tata kelola pemerintahan menjadikan pengelolaan zakat diurus secara khusus.Dalam hal ini dibentuk Baitul Mal Aceh (BMA), Baitul Mal Kota/Kabupaten (BMK) dan Baitul Mal Gampong (BMG). Dasar pembentukan lembaga ini secara beruntun dimulai dari Keputusan Gubernur 05/1973 dengan nama Badan Penertiban Harta Agama (BPHA), BAadan Harta Agama (BHA) tahun 1975, BAZIS/BAZDA tahun 1993, Badan Baitul Mal tahun 2003 dan terakhir Baitul Mal tahun 
2007. Baitul Mal yang terbentuk berdasarkan nomenclatur dari pasal 191 UU No 11 tentang Pemerintahan Aceh tahun 2006. Tahun 2018 Baitul Mal memiliki regulasi terbaru yaitu Qanun 10 tahun 2018 tentang Baitul Mal. Seluruh pengelolaan zakat diatur secara terperinci dalam qanun terbaru ini.

Ditinjau dari tujuan dalam menjalankan fungsinya Baitul Mal Baitul Mal Kabupaten [BMK] Aceh Barat ini haruslah sesuai dengan kenyataan Das Sein dari pada Das Sollen yang seharusnya, karena umumnya sering dalam praktek terjadi ketidak sesuaian antara yang seharusnya dengan kenyataan terjadi sesuai dengan ketentuan Qanun10 tahun 2018 tentang Baitul Mal. Di dalam kenyataanya diketahui bahwa kedudukan, fungsi dan kewenangan Baitul Mal Kabupaten [BMK] Aceh Barat tersebut belum sepenuhnya dijalankan, diantaranya kurangnya sosialisasi dari Baitul Mal sehingga masih ada muzaki yang tidak menyerahkan zakatnya ke Baitul Mal, dalam pengumpulan dan pendayagunaan zakat juga masih banyak kendala yang dihadapi Baitul Mal.

\section{Metodologi Penelitan}

Berdasarkan objek masalah jenis penelitian yang digunakan dalam penulisan tesis ini meliputi penelitian yuridis empiris. Penelitian yuridis empiris atau juga dikenal dengan penelitian non doktrinal, yaitu penelitian berupa studi-studi empiris untuk menemukan teori-teori mengenai proses terjadinya dan mengenai bekerjanya hukum di dalam masyarakat. Tipologi penelitian ini disebut sebagai socio legal research.

Pendekatan yang digunakan populasi dan metode penentuan sampel populasi adalah seluruh obyek atau seluruh individu atau seluruh gejala atau seluruh kejadian atau seluruh unit yang akan diteliti. Populasi dalam penelitian ini adalah semua pihak yang terkait dengan kelembagaan Baitul Mal Kabupaten Aceh Barat.
Penarikan sampel merupakan suatu proses dalam memilih suatu bagian dari suatu populasi yang berguna untuk menentukan bagian-bagian dari obyek yang akan diteliti. Untuk itu, untuk memilih sampel yang representatif diperlukan teknik sampling. Dalam penelitian ini, teknik penarikan sampel yang dipergunakan adalah purposive sampli maksud digunakan teknik ini agar diperoleh subyek-subyek yang ditunjuk sesuai dengan tujuan penelitian.

\section{PEMBAHASAN}

\section{Pengertian Baitul Mal}

Baitul Mal berasal dari bahasa Arab "bait" yang berarti rumah, dan "al-mal" yang berarti harta. Jadi secara etimologis (ma'na lughawi) Baitul Mal berarti rumah untuk mengumpulkan atau menyimpan harta. Secara terminologis (ma'na ishtilahi), sebagaimana uraian Abdul Qadim Zallum (1983) dalam kitabnya Al Amwaal Fi Daulah Al Khilafah yang dikutip $M$. Shiddiq Al Jawi, Baitul Mal adalah suatu lembaga atau pihak (Arab: al jihat) yang mempunyai tugas khusus menangani segala harta umat, baik berupa pendapatan maupun pengeluaran negara.

Alyasa' Abubakar mengartikan Baitul Mal merupakan Lembaga daerah yang berwenang melakukan tugas pengelolaan zakat dan harta agama lainnya. Baitul Mal dipimpin oleh seorang Kepala Badan yang diangkat dan bertanggung jawab kepada Gubernur atau Bupati untuk periode tertentu. Badan Baitul Mal adalah Lembaga daerah non struktural yang di dalam melaksanakan tugasnya bersifat independent. Badan Baitul Mal mempunyai tugas melaksanakan pengelolaan zakat, pembinaan mustahiq dan muzakki serta pemberdayaan harta agama sesuai ketentuan Syariat Islam. 
Pasal 1 Qanun 10 tahun 2018 tentang Baitul Mal terbagi kedalam tiga macam, yaitu;

1. Baitul Mal Aceh yang selanjutnya disingkat BMA adalah Baitul Mal pada tingkat Aceh.

2. Baitul Mal Kabupaten/Kota yang selanjutnya disingkat BMK adalah Baitul Mal pada tingkat Kabupaten/Kota.

3. Baitul Mal Gampong atau nama lain yang selanjutnya disebut BMG adalah lembaga Gampong yang bertugas mengelola zakat, harta wakaf dan harta keagamaan lainnya sesuai dengan prinsip-prinsip syariat.

Chairul Fahmi menjelaskan Baitul Mal Aceh (BMA) adalah sebuah lembaga daerah non struktural yang diberi kewenangan untuk mengelola dan mengembangkan zakat, wakaf, dan harta agama lainnya dengan tujuan untuk kemaslahatan umat serta menjadi wali/wali pengawas terhadap anak yatim piatu dan/atau hartanya serta pengelolaan terhadap harta warisan yang tidak ada wali berdasarkan Syariat Islam.

Sementara selama ini, peran Baitul Mal hanya lebih berperan pada pengelolaan harta zakat secara pasif. Artinya hanya berfungsi sebagai penghimpun dana dan penyalur kepada mustahiq (yang berhak mendapatkan hak zakat). Padahal qanun tersebut telah menyiratkan bahwa peran BMA tidak hanya berfungsi sebagai pengelola, tapi juga mengembangkan zakat tersebut. Dalam hal ini, upaya pengembangan zakat, menjadi sesuatu yang penting, dimana zakat tidak hanya sebagai hal yang konsumtif, namun juga ia lebih produktif. Sehingga harta tersebut tidak hanya habis untuk konsumtif, tapi juga dapat dikembangkan menjadi suatu modal lebih besar, dan dapat dimanfaatkan lebih luas dalam proses pengembagan ekonomi umat secara menyeluruh.

\section{Prinsip Desentralisasi embrio Terbentuknya Peraturan Baitul Mal}

Desentralisasi dan otonomi daerah merupakan bentuk sistem penyerahan urusan pemerintahan dan pelimpahan wewenang kepada daerah yang berada dibawahnya. Otonomi daerah adalah hak, wewenang, dan kewajiban daerah untuk mengatur dan mengurus rumah tangganya sendiri sesuai dengan peraturan perundang-undangan yang berlaku. Pada tingkat yang terendah, otonomi berarti mengacu pada perwujudan free will yang melekat pada diri-diri manusia sebagai satu anugerah paling berharga dariTuhan.Free will inilah yang mendorong manusia untuk mengaktualisasikan diri dan menggali seluruh potensi terbaik dirinya secara maksimal. Berawal dari individu yang otonom tersebut kemudian membentuk komunitas dan menjadi bangsa yang unggul.

Menurut Philipus M. Hadjon : Desentralisasi mengandung makna bahwa wewenang untuk mengatur dan mengurus pemerintahan tidak semata-mata dilakukan pemerintah pusat, melainkan dilakukan juga oleh satuan-satuan pemerintahan yang lebih rendah, baik dalam bentuk satuan teritorial maupun fungsional. Satuan-satuan yang lebih rendah diserahi dan dibiarkan mengatur dan mengurus sendiri sebagian urusan pemerintahan.

Prinsip Desentraliasai berdasarkan tujuan desentralisasi daerah terdiri tiga macam yaitu :

1) Untuk mewujudkan apa yang disebut denan political equality, yakni semakin terbukanya kesempatan bagi masyarakat untuk berpartisipasi dalam berbagai aktivitas politik dan hukum di tingkal lokal.

2) Semakin meningkatnya tanggup jawab pemerintah daerah dalam berhadapan dengan masyarakat (local accountability).

3) Pemerintah daerah, dalam hal ini, dianggap mengetahui lebih banyak tentang berbagai masalah yang dihadapi oleh komunitasnya (local responsiveness). 
Pelaksanaan otonomi daerah tidak terlepas dari keberadaan Pasal 18 UUD 1945. Ketentuan pasal tersebut yang menjadi dasar penyelenggaraan otonomi dipahami sebagai normatifikasi gagasan-gagasan yang mendorong pemakaian otonomi sebagai bentuk dan cara menyelenggarakan pemerintahan daerah. Otonomi yang dijalankan tetap harus memperhatikan hakhak asal usul dalam daerah yang bersifat istimewa. Pasal 18 ayat [6] UUD 1945 menjelaskanPemerintahan daerah berhak menetapkan peraturan daerah dan peraturanperaturan lain untuk melaksanakan otonomi dan tugas pembantuan. Berdasarkan ketentuan yang terdapat di dalam Pasal 18 ayat [6] tersebut, Konstitusi memberikan landasan bagi daerah otonom untuk membentuk peraturan daerah sendiri.

Prinsip desentralisasi dalam penyelenggaraan pemerintahan daerah yang melahirkan otonomi bagi daerah-daerah telah memberikan kewenangan kepada daerah untuk mengurus dirinya dengan cara mengeluarkan produk hukum daerah yang berbasis syariah, ekonomi, pendidikan maupau adat dan kebudayaan. Qanun 10 tahun 2018 tentang Baitul Mal merupakan salah satu produk hukum provinsi Aceh yang berbasis syariah. Qanun ini merupakan peraturan baitul mal yang mengganikan peratuan yang lama yaitu Qanun No 10 tahun 2007 tentang Baitul Mal.

Di dalam asas peraturan-perundangundangan dijelaskan apabila telah ada peraturan perudang-undangan yang baru baik peraturan tingkat pusat maupan peraturan tingkat daerah yang telah di sahkan oleh DPR maka otomatis peraturan yang lama tidak berlaku, lagi dalam hal ini, Titik Triwulan Tutik menjelaskan "undangundang yang berlaku kemudian membatalkan undang-undang yang terdahulu yang mengatur hal tertentu yang sama [lex posteriori derogate legi priori].

Suatu undang-undang tidak berlaku lagi apabila; pertama; jangka waktu berlakunya tidak berlaku yang telah ditentukan oleh undang-undang yang bersangkutan sudah habis.Kedua, keadaan atau untuk hal mana UU itu dibuat sudah tidak ada lagi.Ketiga UU itu dicabut oleh instansi yang membuat atau instansi yang lebih tinggi; keempat, telah ada UU yang baru yang isinya bertentangan atau berlainan dengan UU yang dahulu berlaku. kehadiran Qanun Baitul Mal yang baru untuk bahwa Qanun Aceh Nomor 10 Tahun 2007 tentang Baitul Mal masih belum sepenuhnya menampung perkembangan kebutuhan masyarakat terhadap pengelolaan zakat, infak, wakaf, harta keagamaan lainnya dan perwalian sehingga perlu diganti.

Dalam pasal 4 Qanun Nomor 10 tahun 2018 tentang Baitul Mal menjelaskan susunan organisasi Baitu mal terbagi dua yaitu ;

1. Badan Baitul Mal Aceh [BMA] adalah unsur penyusun dan pembuat kebijakan pengelolaan zakat, infak, harta wakaf, harta keagamaan lainnya dan pengawasan perwalian pada tingkat provinsi di Aceh.

2. Badan Baitul Mal Kabupaten [BMK] adalah unsur penyusun dan pembuat kebijakan pengelolaan zakat, infak, harta wakaf, harta keagamaan lainnya dan pengawasan perwalian pada tingkat Kabupaten/Kota.

Melaksanakan tugas dan fungsinya hubungan antara BMA dan BMK bersifat koordinatif.

\section{Tugas dan Fungsi Baitul Mal}

Adapun tugas dan fungsi Baitul Mal pada dasarnya berasal dari negara Islam sebagai perbandingan dengan keberadaan Baitul Mal di zaman klasik dapat dilihat beberapa refleksi sebagaimana Al Mawardi dalam bukunya Al Ahkam As-Sulthaniyah, menyebutkan Baitul Mal (kas negara), yaitu semua harta yang dimiliki kaum Muslimin dan yang tidak diketahui siapa sebenarnya pemiliknya. Harta tersebut 
menjadi miliki Baitul Mal. Jika permasalan yang demikian, maka kekayaan yang dimiliki kaum muslimin terbagi kedalam tiga bagian, yaitu fai, ghanimah, dan zakat. Mengenai fai dan ghanimah di Provinsi Aceh tidak berlaku sama sekali, ghanimah dan fai berlaku di negara Islam zaman era klasik.

Zakat adalah salah satu rukun Islam yang merupakan ibadah kepada Allah dan sekaligus merupakan amal sosial kemasyarakatan dan kemanusiaan. dalam wujud mengkhususkan sejumlah harta atau nilainya dari milik perorangan atau badan hukum untuk diberikan kepada yang berhak dengan syarat-syarat tertentu, untuk mempersucikan dan mempertumbuhkan harta serta jiwa pribadi para wajib zakat, mengurangi penderitaan masyarakat, memelihara keamanan serta meningkatkan pembangunan. Gubernur Aceh dalam pertimbangannya mengatakan "bahwa dalam rangka pelaksanaan Syariat Islam dan mengoptimalkan pendayagunaan zakat, wakaf, dan harta agama sebagai potensi ekonomi umat Islam, perlu dikelola secara optimal dan efektif oleh sebuah lembaga profesional yang bertanggung jawab dan bahwa dalam kenyataannya, pengelolaan zakat, wakaf dan harta agama lainnya telah lama dikenal dalam masyarakat Aceh, namun pengelolaannya belum dapat secara optimal".

Adapun dalam pasal 3 Qanun 10 tahun 2018 tentang Baitul Mal Penyelenggaraan Baitul Mal bertujuan;

a. Melakukan Pengelolaan dan Pengembangan secara akuntabel, transparan, prudential dan berkesinambungan;

b. Melakukan pengawasan terhadap Nazir dan melakukan pembinaan terhadap Pengelolaan dan Pengembangan Harta Wakaf;

c. Melakukan Pengawasan Perwalian untuk melindungi anak yatim, orang yang tidak cakap melakukan perbuatan hukum dan harta kekayaan mereka;

d. Melakukan Pengembangan dan peningkatan manfaat Zakat, Infak, Harta Wakaf dan Harta Keagamaan lainnya untuk mewujudkan kesejahteraan masyarakat dan penanggulangan kemiskinan; dan

e. Melaksanakan kegiatan lain terkait keberadaan Baitul Mal.

Penyelenggaraan Baitul Mal, berasaskan: keislaman, amanah, profesionalisme, transparansi, akuntabilitas, kemanfaatan, keadilan; keterpaduan; efektifitas dan efisiensi; dan kemandirian

\section{Pengelolaan Zakat Pada Baitul Mal Kabupaten Aceh Barat}

Pengelolaan

merupakan memberdayakan zakat di Baitul Mal Kabupaten Aceh Barat. Adapun yang dimaksud dengan pengelolaan dalam pembahasan ini yaitu segala yang berkaitan dengan pengumpulan, penyaluran dan pengawasan zakat pada Baitul Mal Kabupaten Aceh Barat. Untuk lebih jelasnya mengenai dengan perencanaan, penyaluran dan pengawasan zakat pada Baitul Mal Kabupaten Aceh Barat dapat dijelaskan sebagai berikut:

\section{Penghimpunan}

Baitul Mal Kabupaten Aceh Barat adalah lembaga yang berada di bawah Bupati Aceh Barat. Adapun pengertian"yang berada dibawah Bupati" adalah Baitul Mal dalam menjalankan tugasnya harus bertanggung jawab kepada Bupati Aceh Barat selaku kepala daerah. Baitul Mal Kabupaten Aceh Barat mempunyai Tujuan dan untuk mencapai tujuan tertentu perlu dibentuk struktur organisasi yang gunanya untuk memperjelas tugas pokok dan fungsi Baitul Mal sehingga tujuan dari organisasi dapat tercapai dengan sebaik-baiknya.Tugas pokok Baitul Mal adalah melaksanakan pengelola zakat dan pemberdayaan harta agama sesuai dengan hukum syariat Islam. 
Untuk meningkatkan minat masyarakat membayar zakat melalui Baitul Mal Kabupaten Aceh Barat dilakukan berbagai hal, diantaranyasosialisasidan promosi.Hal senadadekemukakan oleh Afrianto yang mengatakan bahwa "Baitul Mal Aceh Barat selama ini melakukan sosialisasi kepada pedagang dan pengusaha yang memiliki potensi zakat, sosialisasi dilakukan bertujuan untuk menarik minat pedagang dan pengusaha untuk membayar zakatnya melalui Baitul Mal Aceh Barat.

Menurut Cut Laila untuk tahun 2018 jumlah zakat yang diterima oleh Baitul Mal Kabupaten Aceh Barat sebesar Rp 54.014.187.358 dan infaq sebesar $\mathrm{Rp}$ 32.418.515.262, dana zakat sekitar $80 \%$ berasal dari zakat profesi. PNS) dan $20 \%$ lainnya dari non PNS sedangakan infaq merupakan suntikan dana dari pemerintah dan swasta baik berbentuk perserikatan (PT) atau pun perseorang.

Rendahnya jumlah zakat yang terkumpul di Baitul Mal Kabupaten Aceh Barat disebabkan kurangnya kesadaran/ pengetahuan masyarakat dalam hal pentingya membayar zakat terhadap Baitul Mal, yang dikarenakan kurangnya sosialisasi Baitul Mal kepada masyarakat tentang zakat, oleh karena itu lembaga Baitul Mal perlu mengadakan program sosialisasi gerakan sadar zakat, baik melalui seminar-seminar, khutbah-khutbah jum'at, melalui iklan dan lain sebagainya, dan pendataan dan pembinaan muzakki lebih diutamakan. Jadi dalam hal ini Baitul Mal Aceh perlu kerja extra dalam sosialisasi tentang keberadaan baitul mal, dan mengembalikan kepercayaan masyarakat terhadap Baitul Mal, sehingga masyarakat mengenal Baitul Mal dan mempercayakan harta dizakati kepada Baitul Mal Aceh Barat.

\section{Penyaluran}

Al-Qur'an dalam surat at-Taubah ayat 60 telah menjelaskan bahwa ada delapan golongan yang berhak menerima zakat diantaranya: a. Fakir ialah orang yang tidak memiliki kemampuan untuk memenuhi kebutuhan pokok hidupnya.

b. Miskin ialah orang yang memiliki penghasilan atau pekerjaan namun tidak dapat memenuhi kebutuhan hidupnya sendiri maupun keluarga yang ditanggungnya.

c. Amil ialah pengurus zakat baik yang diangkat oleh pemerintah atau masyarakat dalam melaksanakan penghimpunan zakat dan menyalurkannya kepada masyarakat yang membutuhkan.

d. Muallaf ialah orang yang baru memeluk agama Islam yang diberikan zakat untuk memantapkan hati dan keimanan mereka untuk tetap memeluk agama Islam.

e. Hamba sahaya ialah orang yang diberikan zakat untuk membebaskan diri mereka dari perbudakan. Baitul Mal Kabupaten Aceh Barat tidak menemukan hamba sahaya di lingkungan Kabupaten Aceh Barat, dengan demikian asnaf ini ditiadakan dari pembagian zakat pada Baitul Mal Kabupaten Aceh Barat.

f. Gharim ialah orang yang memiliki utang pribadi yang bukan untuk keperluan maksiat dan tidak memiliki harta untuk melunasinya.

g. Fisabilillah ialah orang yang melakukan suatu kegiatan yang berada di jalan Allah, seperti kegiatan dakwah dan sejenisnya.

h. Ibnu sabil ialah orang yang berada dalam perjalanan (Musafir) yang mengalami kesusahan atau kehabisan bekal dalam perjalanan tersebut.

Harta zakat yang didapat diberikan secara komsumtif terutama bagi janda-janda dan orang tua, setiap individu mendapat $\mathrm{Rp}$. 500.000,- sampai Rp.600.000,- dan sisanya diberikan kepada majelis masing-masing untuk mengelolanya, sehingga delapan asnaf mendapatkan seluruhnya, terutama diarahkan pada pengelolaan zakat secara produktif baik melalui pengembangan ekonomi, pendidikan maupun pengembangan dakwah. 
Zakat produktif yang diberikan oleh Baitul Mal Kabupaten Aceh Barat dapat membantu penerima zakat dalam mengembangkan usahanya, hal ini sebagaimana dikemukakan oleh Murni yang mengatakan bahwa "dengan adanya bantuan modal dari Baitul mal dapat membantu usaha yang dijalankan, namun dengan bantuan tersebut belum dapat menjadi muzakki untuk sekarang ini, karena modal yang diberikan sangat sedikit". Pengakuan Murni tersebut senada dengan pengakuan Zulkifli yang mengatakan bahwa "Bantuan modal dari Baitul Mal dapat menambah pendapatannya namun untuk menjadi muzakki sekarang ini masih belum mampu karena pendapat hanya cukup untuk kebutuhan sehari-hari"

Menurut kepala Subbag Umum Baitul Mal Kabupaten Aceh Barat, adadua bentuk mustahiq yang dapat diberikan zakat dari Baitul Mal Kabupaten Aceh Barat yaitu (1). Mustahiq yang di data langsung oleh Baitul Mal Gampong dan (2) Mustahiq yang mengajukan permohonan kepada Baitul Mal Kabupaten Aceh Barat, dalam bentuk bantuan modal usaha.

Dalam melakukan survei kelayakan, Baitul Mal Kabupaten Aceh Barat telah menetapkan standar yang dilakukan pada calon penerima dana zakat yang akan diberikan bantuan. Adapun 2 jenis standar tersebut yakni:

a. Fakir miskin yang sudah menjalankan usaha tetapi tidak mempunyai modal yang cukup untuk mengembangkan usahanya sehingga usaha tersebut bersifat statis.

b. Fakir miskin yang mempunyai potensi untuk berusaha tetapi sama sekali tidak memiliki modal.

Pemberian bantuan modal usaha kepada masyarakat dalam rangka membantu perekonomian masyarakat, bantuan modal usaha diberikan baik dalam bentuk uang maupun barang seperti alat pangkas rambut, mesin jahit dan lain sebagainya.
Dari uraian di atas dapat dipahami bahwa pendistribusian zakat di Baitul Mal Aceh Barat diberikan kepada 8 asnaf sebagaimana telah ditentukan dalam Alqur'an, dalam pembagian zakat diberikan secara konsumtif dan sisanya akan diberikan kepada majelis masing-masing untuk mengelolanya, bantuan zakat yang diberikan oleh Baitul Mal Kabupaten Aceh barat belum mampu menjadikan mustahik menjadi muzakki karena bantuan modal yang diberikan oleh Baitul Mal Kabupaten Aceh Barat sangat sedikit sehingga keuntungan yang diperoleh habis untuk memenuhi kebutuhan sehari-hari.

Dalam penentuan penerima program pendayagunaan zakat produktif tersebut, Baitul Mal Kabupaten Aceh Barat bekerja sama dengan Baitul Mal Gampong yang merekomendasikan mustahiq. Hal ini karena menurut Baitul Mal Kabupaten Aceh Barat, Baitul Mal Gampong lebih tahu siapa diantara warga yang berhak menerima dana zakat produktif sehingga penerima program pendayagunaan zakat produktif akan lebih tepat sasaran.

Persyaratan yang harus ditempuh oleh mustahiq untuk mengajukan bantuan diantaranya adalah:

a. Mengajukan proposal atau identitas diri dengan melampirkan foto copy KTP dan KK;

b. Surat pengantar dari Kelurahan dan Kecamatan setempat;

c. Foto calon mustahiq dan foto tempat usaha;

Sedangkan besaran bantuan yang diberikan pada mustahiq produktif berdasarkan dari kelayakan usaha, kemampuan, kebutuhan dan ketersediaan sesuai hasil verifikasi yang dilakukan oleh petugas. Setelah mustahiq mengajukan persyaratan bantuan, maka Baitul Mal Kabupaten Aceh Barat segera menugaskan pengawas/pendamping untuk melakukan kajian lapangan berkaitan dengan lokasi pendirian usaha, fiktif atau tidaknya usaha 
yang dijalankan bagi mustahiq yang sudah memiliki usaha namun masih bersifat statis karena kurangnya modal, serta menentukan jenis bidang usaha yang sesuai dengan potensi mustahiq bagi mustahiq yang belum menjalankan usaha.

\section{Pengawasan}

Dalam pelaksanaannya, Pengawas/ pendamping juga mengamati kesesuaian antara potensi wilayah dengan bidang usaha yang akan dijalankan calon mustahiq berkaitan dengan pemasaran hasil usaha tersebut. Selain itu, hal ini dimaksudkan untuk mencegah hal-hal yang dapat menghambat usaha mustahiq, kajian lapangan berkaitan dengan potensi personal maupun potensi wilayah ini dilakukan dengan melihat sesuai atau tidaknya jenis bidang usaha yang sedang dijalani mustahiq.

Adapun analisis strategi pengawasan program pendayagunaan zakat produktif menuju kesejahteraan masyarakat yang dilakukan oleh Baitul Mal Kabupaten Aceh Barat berdasarkan tahap-tahap pengawasan adalah:

a. Penetapan standar pelaksanaan

Standar mengandung arti sebagai suatu satuan pengukuran yang dapat digunakan sebagai patokan untuk penilaian hasil-hasil, tujuan, sasaran, kuota, dan target pelaksanaan. Standar pelaksanaan yang terdapat di Baitul Mal Kabupaten Aceh Barat berupa tujuan, sasaran, kuota, dan target pelaksanaan. Dalam realisasinya Baitul Mal Kabupaten Aceh Barat telah menetapkan standar pelaksanaan yang tercermin dalam Program kerja pengurus Bazis.

b. Pengukuran Pelaksanaan kegiatan

Pengukuran pelaksanaan kegiatan bertujuan mengukur pelaksanaan kegiatan secara tepat. Penetapan standar akan sia-sia bila tidak disertai berbagai cara untuk mengukur pelaksanaan dari kegiatan nyata. Beberapa pertanyaan penting yang digunakan untuk menentukan pengukuran pengawasan yaitu berapa kali seharusnya pengawasan diukur, harian, mingguan, bulanan, atau tahunan.

\section{Kendala yang Dihadapi Oleh Lembaga Baitul Mal Dalam Pengelolaan Zakat}

Dalam konsep aslinya seperti yang tersebut dalam ketentuan syara' maupun praktek konkritnya dalam sejarah Islam Baitul Mal merupakan salah satu lembaga dalam negara Islam yang tugas utamanya adalah mengelolah segala pemasukan dan pengeluaran negara. Namun kemudian di Indonesia khususnya Provinsi Nanggroe Aceh Darussalam Baitul Mal dioptimalkan penggunaannya dalam rangka pelaksanaan Syariat Islam. Baitul Mal dalam hal ini dijadikan alat untuk mengoptimalkan pendayagunaan zakat, wakaf, dan harta agama sebagai potensi ekonomi umat Islam, karena zakat perlu dikelola secara optimal dan efektif oleh sebuah lembaga profesional yang bertanggungjawab.

Dalam kenyataannya, pelaksanaan pengelolaan Zakat dan Infaq oleh Baitul Maal belumberjalansecara efektif. Karena tidak erlepas dari adanya berbagai kendala. Hasil penelitian menunjukkan bahwa Ada beberapa kendala yang dihadapi oleh sekretariat Baitul Mal Aceh dalam pengelolaan zakat, di antaranya:

\section{Kualitas Sumber Daya Manusia yang belum memadai.}

Kualitas sumber daya manusia atau dalam Baitul Mal dikenal dengan Sumber Daya Insani merupakam salah satu persoalan yang menjadi penghambat Lembaga Baitul Mal dalam pengelolaan zakat sesuai dengan kewenangan dan fungsinya. Persoalan ini sangat mendasar mengingat sumber daya manusia pada Baitul Mal yang merupakan perangkat daerah sebagai unsur pemberian pelayanan administratif dan mekanisme perekrutannya yang masih terpusat, meskipun kewenangan untuk pelaksanaan 
program peningkatan kualitas SDM ada di daerah.

Kondisi ini menyebabkan sumber daya manusia/insani yang tersedia tidak memadai, padahal yang dibutuhkan sebenarnya mereka yang menguasai dan memahami fiqih islam terutama fiqih muamalah serta juga memahami seluk beluk Baitul Mal. Akan tetapi, tenaga yang memenuhi kualifikasi seperti tersebut tadi masih sangat jarang, karena itu banyak mereka yang bahkan tidak memenuhi kualifikasi direkrut kemudian diberi pelatihan instan, yang akhirnya menjadi pengelola.

\section{Struktur organisasi yang belum memadai.}

Kehadiran peraturan terbaru baitul mal yaitu Qanun no. 10 tahun 2018 tentang Baitul dan belum adanya peraturan Bupati Aceh Barat sebagai aturan pelaksanam maka Struktur kelembagaan Baitul Mal Aceh Barat belun diberlakunya tenaga profesional sepertu yang ada di Baitul Mal Propinsi. Hal ini kemudian menyebabkan terjadinya berbagai hambatan dalam pengelolaan akibat kurang jelasnya penembapat berbagai sumber daya manusia yang tepat pada posisi yang sesuai dengan bidang tugas yang akan dijalankan. Hal ini juga diakibatkan rendahnya kualitas dan kuantitas Sumber Daya Manusia khususnya di bidang akuntansi menjadi persoalan yang berat.

\section{Aspek regulasi.}

Regulasi hukum juga dapat menjadi penyebab timbulnya hambatan bagi Lembaga Baitul Mal dalam pengelolaan zakat. Inkonsistensi dalam penerbitan peraturan perundangan terkait dengan Baitul Mal di berbagai tingkatan berpengaruh besar pada efektif tidaknya Lembaga Baitul Mal dalam pengelolaan zakat.

Tindak konsistensinya antara ketentuan disatu tingkatan dengan tingkatan lainnya menyebabkan pengambil kebijakan dalam Baitul Mal tidak dapat mengambil tindakan operasional yang berguna bagi pelaksanaan tugas dan wewenang penghambat Lembaga Baitul Mal dalam pengelolaan zakat.

\section{Aspek sosialisasi dan pemahaman lembaga pada Masyarakat.}

Sosialisasi keberadaan Lembaga Baitil Mal dalam pengelolaan juga belum sepenuhnya dipahami oleh sebagian masyarakat. Oleh karena itu, masyarakat masih menyalurkan sendiri zakatnyadengan memberikan kepada orang yang dipandang berhak menerimanya. Kondisi ini disebabkan karena kurangnya kepercayaan dan pemahaman kepada lembaga yang berwenang menerima dan menyalurkan zakat seperti halnya Baitul Mal.

Hal ini sebagaimana dikemukakan oleh beberapa warga masyarakat yang menyatakan bahwa pihaknya lebih memilih untuk menyalurkan sendiri zakatnya dengan mengutamakan pemberian zakat kepada fakir miskin yang berada di sekitarnya tempat tinggalnya. Sedangkan untuk menyalurkan kepada lembaga tertentu seperti Baitul Mal takut akan tidak sampai kepada yang berhak

Dengan demikian, walaupun dalam perkembangannya Baitul Mal telah tumbuh sebagai suatu lembaga yang mendapat kepercayaan untuk melakukan pengelolaan zakat, namun tetap saja dalam pelaksanaannya menemui berbagai kendala dan hambatan yang dengan sendirinya berpengeruh besar terhadap eksistensi Lembaga Baitul Mal dalam pengelolaan zakat

\section{Upaya yang Dilakukan Baitul Mal Aceh Barat untuk Mengatasi Kendala Dalam Pengelolaan Zakat d}

Berdasarkan hasil penelitian diketahui bahwa guna mengatasi berbagai hambatan dalam pengelolaan zakat ini, pihak Baitul Mal telah mengambil beberapa langkah dan kebijakan strategis untuk mengoptimalkan kegiatan Baitul Mal, diperlukan beberapa kebijakan strategis, 
Jurnal Sains Riset (JSR)

$p$-ISSN 2088-0952, e-ISSN 2714-531X

http://journal.unigha.ac.id/index.php/JSR

DOI. 10.47647/jsr.v10i12

Mempersiapkan peraturan pelaksana dari Qanun Aceh tentang Baitul Mal

Untuk menindak lanjuti Qanun terbaru Baitul Mal, maka lembaga Baitu Mal Aceh barat wajib mempersiapkan peraturan pelaksana. Peraturan pelaksana yang dimaksud disini adalah mengupayakan pembentukan berbagai ketentuan hukum yang mengatur tentang kedudukan dan kewenangan serta pelaksanaan tugas dan fungsi dari Batul Mal. Dengan kata lain melalui pengadaan ketentuan pelaksana tentang kewenangan Baitul Mal di setiap tingkatan dilengkapi dengan petunjuk operasional dan petunjuk. Teknisnya, seperti Peraturan Bupati Aceh Barat. Keputusan Dewan Syariah Baitul Mal Aceh Barat dan surat keputusan lainya terkait kebijakan Baitul Mal Aceh Barat.

\section{Memperkuat kelembagaan dan personil (capacity building)}

Penguatan kelembagaan Baitul Mal Kabupaten Aceh Barat terutama dalam pengisian personil Dewan Pengawas, Badan Pelaksana Baitul Mal dan tenaga Profesional yang dapat berkerja secara full time. Baitul Mal Kabupaten Aceh Barat setiap tahun melaksanakan RAKER dan BIMTEK, disamping itu juga dilakukan penilaian (assesstment) terhadap kinerja pengurus dan lembaga melalui pemberian \"Zakat Award।" dan saling bekerja sama dan berkoordinasi dengan lembaga Baitul Mal Provinsi.

\section{Memperluas sosialisasi tentang peranan dan fungsi Baitul}

Baitul Mal Kabupaten Aceh Barat melakukan kerjasa dengan pihak Baitul Mal Gampong, perangkat Desa, akdemisi, dan lembaga komunikasi daerah untuk memberikan sosialisasi ke kecamatankecamatan dan gsmpog-gampong. sosialisasi kesadaran berzakat dalam bentuk publikasi media, brosur, talk show televisi (TVRI dan TV Aceh) dan radio (RRI, Baiturrahman dan
TOSS), khutbah, presentasi pada seminar, pelatihan dan work shop dengan lembaga mitra.

Membangun kerjasama dan koordinasi dengan semua instansi terkait, seperti Dinas Syariat Islam, Kanwil Departemen Agama, Perguruan Tinggi, Majelis Ulama, aktivis LSM dan berbagai instansi lainnya

Di samping menetapkan beberapa kebijakan strategis untuk memperkuat kelembagaan, Baitul Mal Aceh setiap tahunnnya melaksanakan beberapa program untuk membangun profesionalitas amil dan sinergisitas program Baitul Mal Kabupaten Aceh Barat. Profesionalitas amil sangat diperlukan, karena diharapkan pekerjaan seorang amil bukan hanya pekerjaan sampingan, tetapi haruslah bersifat profesional serta didukung oleh kebutuhan hidup yang layak.

Kegiatan nyata yang dilakukan Baitul Mal Kabupaten Aceh Barat sejak tahun 2016 telah dilakukan penguatan kelembagaan melalui ;

\section{Bimbingan Teknis Baitul Mal Aceh}

Bimbingan teknis merupakan suatu program mekanisme pengelolaan zakat, infaq, shadaqah serta harta agama lainnya, yang bertujuan untuk meningkatkan profesionalitas karyawan amil. Adapun materi dari Bimbingan Teknis antara: Akuntansi Zakat, Mekanisme Penyusunan Laporan, Majemen Pengeloaan Zakat dan sebagainya.

2. Pelatihan Zakat Produktif

Zakat merupakan salah satu kewajiban yang harus dilaksanakan oleh umat Islam dalam rangka membersihkan jiwa dan hartanya juga sekaligus merupakan salah satu jalan keluar dalam mengangkat harkat dan martabat kaum dhuafa. Potensi zakat sebenarnya di Kabupaten Aceh Barat cukup 
besar. Oleh sebab itu, dengan jumlah zakat yang terkumpul diharapkan dapat mengangkat harkat dan martabat kaum dhuafa melalui pendayagunaan zakat produktif (revolving fund/modal bergulir).

\section{Konsultasi dan Koordinasi Tugas yang bersifat informatif.}

Konsultasi dan Koordinasi dilaksanakan setiap saat antar Baitul Mal Kabupaten Aceh Barat dan Baitul Mal Aceh.

Berdasarkan uraian diatas jelaslah bahwa upaya yang dilakukan untuk mengatasi kendala yang dihadapi Baitul Mal dapat di bagi dalam empat kategori yaitu, adalah (1) mempersiapkan peraturan pelaksana dari Qanun Aceh tentang Baitul Mal, mempersiapkan qanun pelaksana dan Sumber Daya Manusia, (2) memperkuat kelembagaan dan personil (capacity building), (3) memperluas sosialisasi tentang peranan dan fungsi Baitul Mal Aceh, Baitul Mal Kabupaten/Kota dan Baitul Mal gampong, dan (5) membangun kerjasama dan koordinasi dengan semua instansi terkait

\section{Penutup}

\section{Kesimpulan}

a. Penyelenggaraan Fungsi dan Wewenang lembaga Baitul Mal Kabupaten Aceh Barat adalah sebagai salah satu Lembaga Keistimewaan Aceh Kabupaten Aceh Barat Non Struktural (disamping MPU, MAA, dan MPD) dan bertanggung jawab kepada Bupati. Baitul Mal Kapupaten Aceh Barat sebagai Lembaga Keistimewaan Aceh Non Struktural berfungsi untuk mengoptimalkan pendayagunaan zakat, wakaf, dan harta agama sebagai potensi ekonomi umat Islam, perlu dikelola secara optimal dan efektif di kawasan Aceh Barat.

b. Kendala yang dihadapi dalam pengelolaan zakat oleh Baitul Mal Aceh antara lain kualitas sumber daya manusia pelaksana yang belum memadai, kemampuan, struktur organisasi yang belum memadai, aspek regulasi yang belum sejalan antara tingkatan daerah dan aspek sosialisasi dan pemahaman lembaga pada Masyarakat

c. Upaya yang dilakukan Baitul Mal untuk mengatasi kendala yang dihadapi dalam pengelolaan zakat adalah mempersiapkan peraturan pelaksana dari Qanun Aceh tentang Baitul Mal, Memperkuat kelembagaan dan personil (capacity building), memperluas sosialisasi tentang peranan dan fungsi Baitul Mal Kaputen Aceh Barat baik tingkat kecamatan dan tingkat gampong, dan membangun kerjasama dan koordinasi dengan semua instansi terkait.

\section{2, Saran}

a. Disarankan kepada pihak yang berwenang menjalankan pengelolaan zakat melalui Baitul Mal agar dapat menjalankan tugas dan fungsinya sesuai dengan kedudukan dan kewenangan yang ada guna memperoleh kepercayaan masyarakat dalam pengelolaan Zakat.

b. Disarankan kepada masyarakat agar dapat menanamkan rasa percaya dan melaksanakan penyaluran zakat melalui Baitul Mal guna mewujudkan tujuan pembentukan Baitul Mal.

c. Kepada Pemerintah daerah dan juga Lembaga Baitul Mal agar dapat mengupayakan pelaksanaan Syariat Islam dan mengoptimalkan pendayagunaan zakat, wakaf, dan harta agama sebagai potensi ekonomi umat Islam, dengan melakukan pengelolaan secara optimal, efektif, profesional dan bertanggungjawab.

\section{DAFTAR PUSTAKA}

Al Mawardi Al Ahkam Ash-Sulthaniyah( Terjemahan Fadli Bahri, Lc.), (Jakarta Darul Falah, 2005)

Abdul Aziz Dahlan. et.al. 1999.Ensiklopedi Hukum Islam. Cetakan II. PT Ichtiar Baru van Hoeve, Jakarta. 1999 
Jurnal Sains Riset (JSR)

$p$-ISSN 2088-0952, e-ISSN 2714-531X

http://journal.unigha.ac.id/index.php/JSR

DOI. 10.47647/jsr.v10i12

Alyasa' Abubakar, Syariat Islam di Provinsi Nanggro Aceh Darussalam: Paradikma, Kebijakan dan Kegiatan, (Banda Aceh: Dinas Syariat Islam Nanggro Aceh Darussalam, 2005),

Muhammad Hasan, Manajemen Zakat (Model Pengelolaan Yang Efektif), (Yogyakarta: Idea Press, 2011),

Bambang Sunggono, Metode Penelitian Hukum, [Jakarta: PT RajaGrafindo Persada, 2010].

Ronny Hanitijo Soemitro, Metode Penelitian Hukum dan Jurimetri, Ghalia Indonesia, Jakarta, 1990,

Pemerintah Daerah DKI Jakarta, Pengkajian Bidang Otononi Daerah tentang Evaluasi Penyelenggaraan Otonomi Daerah 2004-2006 Dalam Tinjauan Beberapa Aspek, Sekretariat Jenderal Dewan Perwakilan Daerah, Jakarta, 2009,

Pheni Chalid, Otonomi Daerah Masalah, Pemberdayaan an Konflik, Adviser For Decentralization And Regional Autonomy,Perpustakaan Nasional RI: Katalog DalamKemitraan Agustus 2005.

Philipus M. Hadjon, Pengantar Hukum Administrasi Indonesia: Introduction to The Indonesian Administrative law, [Yogyakarta; Gadja Mada Universitay Press, 2008],

Titik Triwulan Tutik, Konstruksi Hukum Tata Negara Indonesia Pasca Amandemen UUD 1945, (Jakarta; Kencana Prenda Group, 2010).
Tim Peneliti Universitas Hasanuddin, Esensi Dan Urgensitas Peraturan Daerah Dalam Pelaksanaan Otonomi Daerah, Kerjasama Dewan Perwakilan Daerah Republik Indonesia dan Universitas Hasanuddin, Makasar, 2009.

Qanun Aceh Nomor 10 tahun 2018 tentang Baitul Mal

Qanun Aceh Nomor 10 tahun 2007 tentang Baitul Mal

www.google.co.id/baitulmal, diakses pukul 12.30 tanggal 25 Januari 2021

https://baitulmal.bandaacehkota.go.id/ diakses pukul 14.54 Februari 2021

Hasil Wawancara Denagan Afrianto, Sub. Bagian Umum Perencanaan dan Publikasi Baitul Mal Kabupaten Aceh Barat, Tanggal 4 Januari 2021

Hasil Wawancara Dengan Said Ikhsan, Kepala Sekretariat Baitul Mal Aceh Barat, tanggal tanggal 12 Januari 2021

Hasil Wawancara dengan Mahdi Kari, Bagian Pendistribusian dan Pemberdayaan Zakat Baitul Mal Aceh Barat, tanggal 5 Januari 2021

Hasil Wawancara dengan Cut Laila, Seksi Penerimaan dan Pelaporan Pada Baitul Mal Aceh Barat, tanggal 4 Januari 2021 